Op Ology

Mini Review

Journal of Nutrition, Food Research and Technology

\title{
Spices; a mechanistic anticancer treatise
}

\author{
Muhammad Hanif Mughal
}

Homeopathic Clinic, Islamabad, Pakistan

Correspondence: Muhammad Hanif Mughal, Homeopathic Clinic, Islamabad, Pakistan, Email mic_I661@yahoo.com

Received: February 15, 2019 | Published: April 18,2019

Copyright@ 2019 Mughal. This is an open access article distributed under the terms of the Creative Commons Attribution License, which permits unrestricted use, distribution, and reproduction in any medium, provided the original author and source are credited.

\begin{abstract}
Spices are the promising and cost effective choice due to their high antioxidant activity, ability to triggers the free radicals scavenging ability at cellular level thereby alleviating various metabolic syndromes. They are good and enrich source of bioactive moieties such as curcuminoids, curcumin limonene, allicin, cinnamic aldehyde, 2-hydroxycinnamaldehyde, allyl isothiocyanate, eugenol, zingiberone, gingerol, dipropyle disulfides, and zingiberene, have been identified as chemo-preventing agents against various malignancies. Chemo-preventive properties of spices are mediated by functional bioactive ingredients that arrest the activity of cytochrome P450 and isozymes CYP
\end{abstract}

1A1, cyclooxygenase-2, reducing activator of transcription-3 (STAT-3) and signal transducer. They are closely associated with tumorigenesis activated by interleukin-6 (IL-6) receptors and epidermal growth factors (EGF) relate to an array of tumors. They altered the expression of protein involved in cell cycle, activating caspases killer and suppressing Kappa-B activation. The current review article explains the health endorsing perspectives of all spices and their daily use in life.

Keywords: Spices, composition, chemo-preventive agent, anticancer potential, anti-diabetic role

\section{Introduction}

There are approximately 180 spice-derived bio-active components have been reported as effective against various degenerative human diseases. ${ }^{1}$ Herbs and spices are widely utilized as preventive and curative agents in degenerative diseases in Middle East since approximately $5000 \mathrm{BC}^{2}$ These spices showed an impressive biological responses and curing role against wide arrange of ailments such as cancer, diabetes, cardiovascular and etc. These are potential source of chemical substances such as polyphenols, flavonoids, quinines, polypeptides, terpenoids, alkaloids and behaved like as antioxidant. They are valuable mixtures of mainly terpenoids like geraniol, linalool, menthol, $\alpha$-terpineol, borneol, citronnillol, thujanol, and phenols including carvacrol, thymol, gaiacol, and eugenol and aromatic aldehydes i.e. cuminal, cinnamaldehyde, and phellandral. These are isolated from different parts of the plant such as buds, seeds, flowers, twigs, leaves, wood, bark, and roots. ${ }^{3}$ Spices and herbs suppress the oxidative rancidity, slow down the development of offflavor and retardation of microbial growth in food containing products such as snack foods and meat products. ${ }^{4}$

\section{Turmeric}

Turmeric (Curcuma longa) belongs to Zingiberaceae and comprises phenolic compounds and terpenoids such as diarylpentanoids, diarylheptanoids, sesquiterpenes, monoterpenes, triterpenoids, diterpenes, sterols, and alkaloid etc. Curcumin (diferuloyl methane) as the principal compound is comprises of $3-15 \%$ of turmeric and was isolated in 1815, while its chemical structure was determined in 1910 (Figure 1). It is a mixture of three curcuminoids $71.5 \%$ curcumin (curcumin I) (1), 19.4\% demethoxycurcumin (curcumin II) (2), and $9.1 \%$ bisdemethoxycurcumin (curcumin III). ${ }^{5}$ Singh and Aggarwal ${ }^{6}$ determined that turmeric suppressed the activation of NF- $\mathrm{\kappa B}$ induced by PMA, TNF- $\alpha$, or $\mathrm{H}_{2} \mathrm{O}_{2}$ through blocking the phosphorylation of IKK $\alpha$. It abrogates LPS induced mitogen activated protein kinase (MAPK) activation and the translocation of NF-kB p65 in DCs.
Curcumin down regulates TNF- $\alpha$ induced NF- $\mathrm{KB}$ activation. In addition to, curcumin also blocks $\mathrm{I} \kappa \mathrm{B} \alpha$ degradation, cytokine-induced NF-אB DNA binding activity, IKK activity in HT-29, RelA nuclear translocation, I $\mathrm{K} \mathrm{B}$ serine 32 phosphorylation, Caco-2, and EC-6 cells. The previous explorations of Kato et al. ${ }^{7}$ determined that high administration of curcumin high-dose of curcumin inhibited the BCGinduced IL-8 production and LPS-mediated TLR2 mRNA induction on mouse splenic macrophages in human monocytes and gingival fibroblasts through suppressing NF- $\mathrm{KB}$ activation. Likewise, it also inhibits the activity of NF- $\mathrm{KB}$ in primary ATL cells and HTLV-1 infected T-cell lines by abolished constitutive phosphorylation of Taxinduced $\mathrm{NF}-\kappa \mathrm{B}$ transcriptional activity and $\mathrm{I} \kappa \mathrm{B} \alpha{ }^{8}$<smiles>COc1cc(/C=C/C(=O)/C=C(O)/C=C/c2ccc(O)c(OC)c2)ccc1O</smiles>

Curcumin<smiles>C=C(C)C1CC=C(C)CC1</smiles>

Limonene

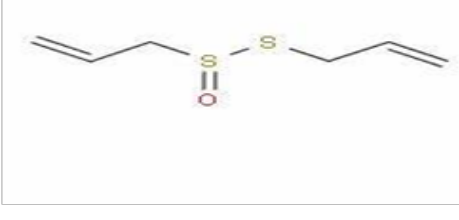

Allicin
Figure I Chemical compounds in spices 
Curcumin also showed the anti-carcinogenic and chemopreventive role against numerous targets such as, apoptotic genes, growth regulators, adhesion molecules, cellular signaling molecules, transcription factors, and angiogenesis regulators. Curcumin also inhibits the activation of activator protein-1 (AP-1) by blocking phosphorylation

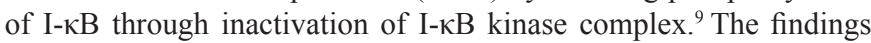

of Leu and $\mathrm{Maa}^{10}$ assessed that curcumin reduced the activity of a number of different enzymes including cytochrome P450 and COX2. Similarly, it also induced apoptosis in a number of different cells including prostate cancer cells, inhibited the AP-1 and down regulates endogenous bcl-2 and baxxL proteins in DU145 cells. ${ }^{11}$

Table I Chemical composition of spices

\begin{tabular}{|c|c|c|}
\hline Spices & Constituents & References \\
\hline Turmeric & $\begin{array}{l}\text { sesquiterpenes, monoterpenes, triterpenoids, } \\
\text { diterpenes, sterols }\end{array}$ & 5 \\
\hline Clove & eugenol, alpha-terpinyl acetate, alpha-humulene & 12 \\
\hline Basil & carvacrol, borneol, methyl eugenol, iedol & 15 \\
\hline Cumin & Thymoquinone, cuminaldehyde & 22 \\
\hline Ginger & $\begin{array}{l}\text { beta-bisabolene, curcumene, betaphellandrene, } \\
\text { camphene }\end{array}$ & 25 \\
\hline Garlic & $\begin{array}{l}\text { alliin, cycroalliin, diallyl disulphide (DADS), and } \\
\text { ajoene, } \beta \text {-phellandrene }\end{array}$ & 29 \\
\hline
\end{tabular}

Table 2 Anticancer role of spices

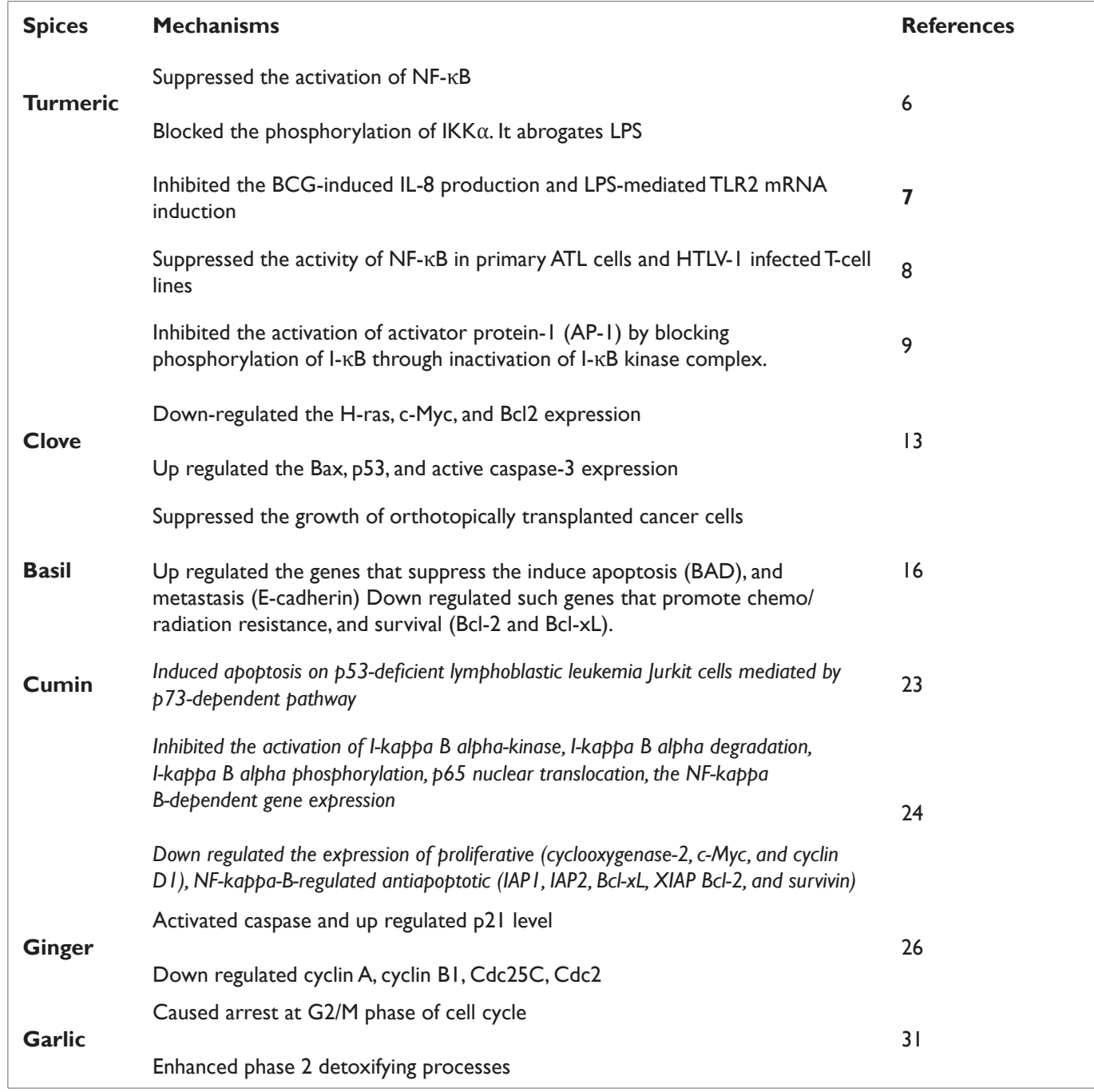




\section{Clove}

The herbs and spices stimulates the pancreas to interfere with dietary glucose absorption, produce and recreate insulin, and insulin sparing action of the bioactive ingredients. Clove is prominent source of essential oils such as caryophyllene, eugenol, alpha-terpinyl acetate, alpha-humulene, methyl eugenol, eugenyl, naphthalene, actyl eugenol, heptanone, sesquiterpenes, chavicol, vanillian, and methyl salicylate pinene and used in many food based products. ${ }^{12}$ Skin tumors were induced by application of DMBA croton oil and eugenol was orally administered for 15 days to subjects to curtain the cancer effects. Eugenol treated mices were developed the $42 \%$ skin anti-tumor effect as compared to control rats. The mean height $(0.519 \mathrm{~cm})$ of skin tumors of eugenol treated group was significantly higher than control group $(1.789 \mathrm{~cm})$. The orally administrated euegenol is restricted the proliferation of carcinogenesis at the premalignant stage. It also down-regulates the $\mathrm{H}-\mathrm{ras}, \mathrm{c}-\mathrm{Myc}$, and $\mathrm{Bcl} 2$ expression along with up regulates the Bax, p53, and active caspase- 3 expression in the skin lesions of the rats. Furthermore, eugenol protects the depletion of GSH and antioxidant enzymes caused by TPA. ${ }^{13}$ Prakash and Gupta ${ }^{14}$ determined that orally administrated clove protect the living organism from damage caused by free radicals, lipid per-oxidation, DNA strand breaking, and protein damage. ${ }^{14}$

\section{Basil}

The basil (Ocimum sanctum) belongs to family Labiatae. It is promising source of essential oil such as octane, $\alpha$-Thujene, ethyl 2-methyl butyrate, $\alpha$-pinene, (Z)-3-hexanol, myrecene, $\beta$-pinene, limonene (Figure 1), ethyl benzene, allo-oc-imene, terpiniolene, $\alpha$-cubebene, butyl-benzene, eugenol, linalool, carvacrol, borneol, methyl eugenol, iedol, humulene oxide, germacrene-D, $\tau$-cadinol, $\alpha$-guaiol, (EZ)-famesol, $\alpha$ - bisbolol, elemol, cissesquisainene hydrate, selin-11-en-4- $\alpha$-ol, tetradecanal, and 14-hydroxy-f-humulene. These bioactive ingredients depends on the processing \& storage conditions, type of soil, and harvesting time. ${ }^{15}$ Basil bioactive compounds suppress the different stages of cancer such as invasion, migration, proliferation, and induce apoptosis of cancer cells. They also down regulate the FAK, activated ERK-1/2, and p65 (subunit of NF- $\mathrm{KB}$ ). The aqueous extract of basil considerably suppresses the growth of orthotopically transplanted cancer cells. It up regulated the genes that suppress the induce apoptosis (BAD), and metastasis (E-cadherin) and down regulated such genes that promote chemo/radiation resistance, and survival (Bcl-2 and Bcl-xL). ${ }^{16}$ Basil possesses the anticancer mechanisms through the following (1) lowering nitric oxide amount, decreasing the incidence of 3-methyl di-methyl amino azobenzene, and benzo (a) pyrine-induced neoplasia and inducing hematomas in rats. ${ }^{17}$ The utilization of ethanolic extract of basil leaves significantly lower the values of paplliomas tumor incidence in the skin of albino mice. ${ }^{18}$ Another group of researchers, they noted that basil reduced the size of tumor cells and enhanced the life expectancy of mice having Sarcoma-180 solid tumors. The promising components of basil plant such as urosolic acid and oleanlic acid exhibit anticancer activity in Lewis- lung carcinoma rats. ${ }^{19}$ The alcoholic extract of basil plant enhances the activities of cytochrome b5, glutathione S-transferase, cytochrome $\mathrm{p} 450$, and aryl hydrocarbon hydroxylase that detoxify the carcinogens and mutagens. ${ }^{20}$

\section{Cumin}

Cumin (Nigella sativa. L) belongs to family Ranunculaceae and is promising source of thymoquinone, thymol and dithymoquinone compounds. These compounds are effective against cardiovascular, different types of human cancers, diabetes complications, kidney disease, asthma etc. ${ }^{21}$ Thymoquinone (TQ) shows anti-cancer effect against human myeloblastic leukemia HL-60 cells. It also induces apoptosis linked with DNA laddering and a decrease in mitochondrial membrane potential in 518A2 melanoma and HL-60 cells. Thymoquinone inhibits the MCF-7 breast cancer cells lines in mice. ${ }^{22}$

It also induces apoptosis in HepG2 cell line. It also induces apoptosis on p53-deficient lymphoblastic leukemia Jurkit cells mediated by p73-dependent pathway that targets the epigenetic integrator UHRF1 and HDAC1, and DNMT1. ${ }^{23}$ Thymoquinone suppresses the NF-kappa $B$ activation through inhibition of the activation of I-kappa B alpha-kinase, I-kappa B alpha degradation, I-kappa B alpha phosphorylation, p65 nuclear translocation, the NF-kappa $B$-dependent gene expression, and $p 65$ phosphorylation. It inhibits the direct binding of recombinant p65 and nuclear p65 to the DNA, and this binding was reversed by DTT. It did not suppress $p 65$ binding to DNA when cells were transfected with the p65 plasmid containing cysteine residue 38 mutated to serine. It also down regulates the expression of proliferative (cyclooxygenase-2, $c-M y c$, and cyclin D1), NF-kappa-B-regulated antiapoptotic (IAP1, IAP2, Bcl-xL, XIAP Bcl2, and survivin), and angiogenic (vascular endothelial growth factor and matrix metalloproteinase-9) gene products. ${ }^{24}$

\section{Ginger}

Ginger (Zingiber officinale) belongs to the Zingiberaceae and prominent source of gingerol (5-hydroxy-1-(4-hydroxy3-methoxy phenyl) decan-3-one. It comprises of carbohydrates $60-70 \%$, water $9-12 \%$, protein $9 \%$, ash $8 \%$, fatty oil $3-6 \%$, crude fiber $3-8 \%$, and volatile oil $2-3 \%$. It is also promising source of essential volatile oils including $30-70 \%$ alpha-zingiberene, $15-20 \%$ beta-sesquiphellandrene, $10-15 \%$ beta-bisabolene, curcumene, betaphellandrene, camphene, and zingiberene. Gingerol suppresses the production of reactive oxygen species induced by ferric chloride $\mathrm{FeCl} 3$-ascorbatesystem and also inhibits the oxidation activity of xanthine. It also enhances the concentration of catalase and SOD in the tissues whilst the level of oxidized glutathione lowers. Likewise, it inhibits the colon carcinogenesis induced through aprocarcinogen, dimethylhydrazine $(\mathrm{DMH}){ }^{25}$

The previous findings of $\mathrm{Hsu}$ et al. ${ }^{26}$ demonstrated that 6-dehydrogingerdione (DGE) prevented from the breast cancer through activating caspase, up regulating p21 level and down regulating cyclin $\mathrm{A}$, cyclin $\mathrm{B} 1, \mathrm{Cdc} 25 \mathrm{C}, \mathrm{Cdc} 2$, and hence arrested cells at G2/M phase and caused apoptosis. Similarly, 6-gingerol has anticancer effect on cell proliferation, NF- $\mathrm{B}$ activation, and angiogenesis and also arrests cell cycle at G1 phase through down regulating cyclin D1. In addition to, 6-paradol and 6-gingerol have exhibited a strong anti-cancer activity through inhibiting TNF- $\alpha$ production in TPA-treated female ICR-mice. Apparently, ginger work as an anti-cancer agent through blocking NF- $\mathrm{kB}$ activation by the inhibition of TNF- $\alpha$ pro-inflammatory cytokine..$^{27}$

\section{Garlic}

Garlic (Allium sativum L) is the most widely researched and oldest cultivated plant and has been used in food based products for over 4000 years. The garlic word was derived from the Anglo-saxon 'gar-leac' or spear plant. It contains more than 200 chemical compounds and more important compounds are allicin (Figure 1), alliin, cycroalliin, dialllyl disulphide (DADS), and ajoene, $\beta$-phellandrene, geraniol, citral, a-phellandrene, linalool and enzymes (allinase, myrosinase, and peroxidase). ${ }^{28}$ Regarding pharmacological role, garlic has potential to 
prevent the cells from the different cancer stages through neutralizing free radicals, enhancing glutathione contents, increasing the activities of antioxidant enzymes i.e. s-transferease, glutathione, catalase, suppression of cytochrome p4502E1, preventing of chromosomal damage1, and DNA repair mechanisms. As an anti-carcinogenic agent, garlic and its organosulfur compounds (OSCs) inhibit the cell proliferation through blocking cell cycle progression, inhibition of DNA adduct formation, inducing apoptosis, up regulation of antioxidant defenses, modulation of carcinogen metabolism, and DNA repair systems. ${ }^{29}$ These dietary bioactive OSCs modulate the cancer cascades and acts as potential chemo preventive and chemotherapeutic agents. ${ }^{30}$ The selenium-enriched garlic or garlic sulfur analogues and its extracts exhibit the higher rate of inhibition of progression of carcinogenesis and breast cancer cells in rats. The garlic and its oil soluble compounds such as diallyl disulfide (DADS) are more effective to synergize the effect of antagonize the effect of linoleic acid and eicosapentaenoic acid. These sulphur containing compounds suppress the carcinogen activation, cause arrest at G2/M phase of cell cycle, enhance phase 2 detoxifying processes, increase acetylation of histones, induce mitochondrial apoptotic pathway, influence gap-junctional intercellular communication, involvement in signal transduction, modulation of cellular redox state, and posttranslational modification. ${ }^{31}$

\section{Cinnamon}

Cinnamon is primarily used in the food based products such as perfumes, and medicinal due to its fragrance. Cinnamon is prominent source of cinnamaldehyde and trans-cinnamaldehyde essential oils that exhibited various health endorsing properties. ${ }^{32}$ It is promising source of several bioactive components i.e. cinnamaldehyde, cinnamic acid, cinnamate, and several essential oils including cinnamyl acetate, transcinnamaldehyde, L-borneol, eugenol, b-caryophyllene. Cinnamon shows the anticancer activity in mouse melanoma that are mediated by modulation of angiogenesis and cytotoxic activity of CD8+ T cells. It also induced the apoptosis in a cancer cells lines. Similarly, it reduces the levels and activities of AP1 and NF-kB and their target genes such as Bcl-2 and BclxL. ${ }^{33}$ Moreover, cinnamon significantly decreases the growth rate of $\mathrm{SiHa}$ cells in a dose dependent manner and restricts the growth of cervical cancer cells in rats. ${ }^{34}$ The photo-chemo-preventive activity through suppressing reactive oxygen species-induced photooxidative stress in cells of human skin were reported. Similarly, oral supplementation of cinnamon and cinnamaldehydes suppressed the thioredoxin reductase and activated the Nrf2 in a murine xenograft model of the disease. ${ }^{35}$ Cinnamon and its polyphenols extract suppressed the proliferation of cancer cells lines and induced cell death of tumor cells through inhibiting AP1 and NFkappaB activity and their target genes i.e. BcL-xL, Bcl-2, and up-regulating proapoptotic molecules. ${ }^{33}$ It also lowers the levels of HIF-1a and Cox-2 in melanoma cell lines and in the melanoma mouse model. ${ }^{36}$ Cox- 2 expression is associated with growth factors such as FGF, EGF, and VEGF and cytokines including IL1-b, and TNF-a. The increased level of Cox-2 enzyme is led to tumor progression through inducing angiogenic and metastatic progression and immune suppression. Hence, cinnamon treatment lowers the Cox-2 and HIF-1a expression in the tumor tissues. ${ }^{36}$

\section{Rosemary}

Rosemary (Rosmarinus officinalis L.) belongs to the family Lamiaceae and is being used as a food flavoring agent due to its powerful antimicrobial, anticancer, anti-diabetic activities and also as a chemo-preventive agent. ${ }^{37}$ It constitutes a wide variety of bioactive phytochemicals such as, carnosic acid, carnosol, 7-methylepirosmanol, rosmanol, rosmadial, isorosmanol, rosmaridiphenol, caffeic acid, and rosmariquinone, approximately $90 \%$ of the antioxidant activity of rosemary is owing to the presence of carnosol and camosic acid.$^{38}$ Chemoprevention is a strategy to the administration of chemical agents, individual drugs and as naturally occurring compounds to curtail the effects of cancer proliferation. Rosemary extracts lowers the NF- $\kappa \mathrm{B}$ activation, TNF- $\alpha$-induced ROS generation, and then enhanced the TNF- $\alpha$-induced apoptosis..$^{39}$ Carnosol is induced the apoptotic cell death in lymphoblastic leukemia carnosol and lowered the tumor proliferation. It also reduces the cell death in the pre-B ALL lines REH, and SEM, RS4;11. Rosemary bioactive compounds show the anticancer activity through enhancing the serum level of CYT-C in colorectal cancer-induced rats. This anticancer activity is attributed due to carnosol, rosmarinic acid, carnosic acid, rosmanol and ursolic acid compounds. ${ }^{40}$ In another study, Kim et al.$^{41}$ determined that ursolic acid suppress the different stages of cancer such as tumorigenesis, tumor promotion, and angiogenesis. Ursolic acid induces apoptosis in human breast cancer cell line, MDA-MB-231 and lowers the cell proliferation rate. It also induces apoptotic molecules related to either extrinsic or intrinsic apoptosis signal pathway in MDA-MB-231 cells. $^{42}$

\section{Oregano}

The oregano (origanum vulgare) belongs to family Lamiaceae and comprises of oleanolic acid, flavonoids, ursolic acid, caffeic, terpinene, hydroquinones, p-cymene, carvacrol, lithospermic, thymol, and rosemarinic acids, and tannins. Phenolic compounds have $71 \%$ of the total oil. ${ }^{43}$ The ethanol crude extract of oregano show antiproliferative activity in MCF-7 human breast adenocarcinoma cell lines. ${ }^{44}$ The earlier findings of Yin et al. ${ }^{45}$ determined that carvacrol suppressed the growth of human hepatocellular carcinoma cell line HepG-2 through inducing apoptosis. The investigations of Sriharia et al. ${ }^{46}$ determined that oregano exhibited the anticancer activity through the suppression of the development of induced colon cancer in rats in a dose and time dependent manner. It also has preventive role against radition induced DNA damage and oxidative stress. Carvacrol and thymol protect the DNA from variety damaging agents and inhibit the proliferation of cancer cells. ${ }^{47}$ Likewise, Stanojković et al. ${ }^{48}$ observed that oregano extract exhibited the significant proliferative activity against human breast cancer cell lines (MDR-MB-453), and (MDAMB-361).

\section{Conclusion}

The spices and bioactive molecules have been found for their promising phytochemical profiles. A summary of the chemical compositions of spices and their anticancer mechanisms can be seen in Tables 1 and 2 . The chemical structures These phytochemicals include chlorogenic acid, caffeic acid and kaempferol which exert strong anticancer potential against different human cancer cells lines. These compounds also induce apoptosis, caused cell cycle arrest, and suppress the invasion and suppression of cancer cells lines. Researchers and investigators are trying to explore new phytochemicals which have been could be open the new horizons to treat other human disorders.

\section{References}

1. Aggarwal BB, Kunnumakkara AB, Harikumar KB, Tharakan ST, Sung B, An P, Aggarwal BB. Targeting inflammation-induced obesity and metabolic diseases by curcumin and other nutraceuticals. Annu Rev Nutr. 2010;30: 173-99. 
2. Chang J. Medicinal herbs: drugs or dietary supplements? Curr. Opin Otolaryngol. Head Neck Surg. 2006;14(3): 191-6.

3. Perumalla AVS, Hettiarachchy NS. Green tea and grape seed extracts Potential applications in food safety and quality. Food Res Int. 2011;44: $827-839$.

4. Duke AJ. Handbook of Legumes of World Economic Importance, Plemus Press, New York and London. 1986;pp: 345

5. Pfeiffer E, H€ohle S, Solyom A, Metzler M. Studies on the stability of turmeric constituents. J. Food Eng. 2003;56: 257-259.

6. Singh S, Aggarwal BB. Activation of transcription factor NF-kappa $\mathrm{B}$ is suppressed by curcumin (diferuloylmethane). J. Biol. Chem. 1995;270(42): 24995-5000.

7. Kato S, Yuzawa Y, Tsuboi N, Maruyama S, Morita Y, Matsuguchi T, Matsuo S. Endotoxin-induced chemokine expression in murine peritoneal mesothelial cells: the role of toll-like receptor 4. J Am Soc Nephrol. 2004;(5): 1289-99.

8. Jung KK, Lee HS, Cho JY, Shin WC, Rhee, MH, Kim TG, Kang JH, Kim SH, Hong S, Kang SY. Inhibitory effect of curcumin on nitric oxide production from lipopolysaccharide-activated primary microglia. Life Sci. 2006;79(21): 2022-31.

9. Surh YJ, Han SS, Keum YS, Seo HJ, Lee SS. Inhibitory effects of curcumin and capsaicin on phorbol ester-induced activation of eukaryotic transcription factors, NF-kappaB and AP-1. Biofactors. 2000;(1-4): 107 12 .

10. Leu TH, Maa MC. The molecular mechanisms for the antitumorigenic effect of curcumin. Curr. Med. Chem. Anticancer Agents. 2002;2(3): 357 70

11. Dorai T, Cao YC, Dorai B, Buttyan R, Katz AE. Therapeutic potential of curcumin in human prostate cancer. III. Curcumin inhibits proliferation, induces apoptosis, and inhibits angiogenesis of $\mathrm{LNCaP}$ prostate cancer cells in vivo. Prostate. 2001;47(4): 293

12. Kim SH, Hynu SH, Choung SY. Anti-diabetic effect of cinnamon extract on blood glucose in db/ db mic. J. Ethno. Pharmacol. 2006;104(1): 119123

13. Kaur G, Athar M, Alam MS. Eugenol precludes cutaneous chemical carcinogenesis in mouse by preventing oxidative stress and inflammation and by inducing apoptosis. Mol. Carcinog. 2010;49(3): 290-301.

14. Prakash P, Gupta N. Therapeutic uses of Ocimum sanctum Linn (Tulsi) with a note on eugenol and its pharmacological actions: a short review. Indian J. Physiol. Pharmacol. 2005;49(2): 125-31.

15. Kothari SK, Bhattacharya AK, Ramesh S. Essential oil yield and quality of methyl eugenol rich Ocimum tenuiflorum L. f. (syn. O. sanctum L.) grown in South India as influenced by method of harvest. J Chromatogr. 2004;1054: 67-72.

16. Shimizu T, Torres MP, Chakraborty S, Souchek JJ, Rachagani S, Kau S, Macha M, Ganti AK, Hauke RJ, Batra SK. Holy Basil leaf extract decreases tumorigenicity and metastasis of aggressive human pancreatic cancer cells in vitro and in vivo: potential role $i$

17. Kim SO, Kundu JK, Shin YK, Park JH, Cho MH, Kim TY, Surh YJ [6]-Gingerol inhibits COX-2 expression by blocking the activation of p38 MAP kinase and NF-kappaB in phorbol esterstimulated mouse skin. Oncogene. 2005;24: 2558-2567.

18. Prashar R, Kumar A, Hewer A, Cole KJ, Davis W, Phillips, DH. Inhibition by an extract of Ocimum sanctum of DNA-binding activity of 7 12-dimethylbenz [a] anthracene in rat hepatocytes in vitro. Cancer Lett. 1998;128: 155-160

19. Singh V, Amdekar S, Verma O. Ocimum tanuiflorum (Tulsi): Biopharmacological activities. Pharmacol. 2010;1(10).
20. Govind P, Madhuri S. Medicinal plants: Better remedy for neoplasm. Indian Drug. 2006;43(11): 869-874.

21. Lutterodt H, Luther M, Slavin M, Yin JJ, Parry J, Gao JM, Yu L. Fatty acid profile, thymoquinone content, oxidative stability, and antioxidant properties of cold-pressed black cumin seed oils. LWT-Food Sci. Tech. 2010;43: 1409-1413

22. El-Aziz MA, Hassan HA, Mohamed MH, Meki AR, Abdel-Ghaffar SK Hussein MR. The biochemical and morphological alterations following administration of melatonin, retinoic acid and Nigella sativa in mammary carcinoma: an animal model. Int J Exp Pathol. 2010;8

23. Alhosin M, Abusnina A, Achour M, Sharif T, Muller C, Peluso J, Chataigneau T, Lugnier C, Schini-Kerth VB, Bronner C, Fuhrmann G. Induction of apoptosis by thymoquinone in lymphoblastic leukemia Jurkat cells is mediated by a p73-dependent pathway which targets the epigenetic integrator UHRF1. Biochem Pharmacol. 2010;79(9): 1251-60.

24. Sethi G, Ahn KS, Sung B, Kunnumakkara AB, Chaturvedi MM, Aggarwal BB. SH-5, an AKT inhibitor potentiates apoptosis and inhibits invasion through the suppression of anti-apoptotic, proliferative and metastatic gene products regulated by IkappaBalpha kinase activation. Biochem. Pharmacol. 2008;76(11): 1404-16.

25. Manju V, Nalini N. Chemopreventive efficacy of ginger, a naturally occurring anticarcinogen during the initiation, post-initiation stages of 1,2 dimethylhydrazine-induced colon cancer. Clin. Chim. Acta. 2005;358(12): $60-7$.

26. Hsu YL, Chen CY, Hou MF, Tsai EM, Jong YJ, Hung CH, Kuo PL. 6-Dehydrogingerdione, an active constituent of dietary ginger, induces cell cycle arrest and apoptosis through reactive oxygen species/c-Jun N-terminal kinase pathways in human breast cancer cells. Mol Nutr Food Res. 2010;54(9): 1307-1317.

27. Park KK, Chun KS, Lee JM, Lee SS, Surh YJ. Inhibitory effects of [6]-gingerol, a major pungent principle of ginger, on phorbol esterinduced inflammation, epidermal ornithine decarboxylase activity and skin tumor promotion in ICR mice. Cancer Lett. 1998;1

29. Nagini S. Cancer chemoprevention by garlic and its organosulfur compounds-panacea or promise? Anticancer Agents Med Chem. 2008;8(3): 313-21.

30. Tsubura A, Lai YC, Kuwata M, Uehara N, Yoshizawa, K. Anticancer effects of garlic and garlic-derived compounds for breast cancer control. Anticancer Agents Med Chem. 2011;11(3):249-53.

31. Iciek M, Kwiecień I, Włodek L. Biological properties of garlic and garlicderived organosulfur compounds. Environ Mol Mutagen. 2009;50(3): 247-65.

32. Yeh HF, Luo CY, Lin CY, Cheng SS, Hsu YR, Chang ST. Methods for thermal stability enhancement of leaf essential oils and their main constituents from indigenous cinnamon (Cinnamomum osmophloeum). $J$ Agric Food Chem. 2013;61(26): 6293-8.

33. Kwon HK, Hwang JS, So JS, Lee CG, Sahoo A, Ryu JH, Jeon WK, Ko BS, Im CR, Lee S H, Park ZY, Im SH. Cinnamon extract induces tumor cell death through inhibition of NFkappaB and AP1. BMC Cancer. 2010;10: 392 .

34. Schoene NW, Kelly MA, Polansky MM, Anderson RA. Watersoluble polymeric polyphenols from cinnamon inhibit proliferation and alter cell cycle distribution patterns of hematologic tumor cell lines. Cancer Lett. 2005;230: 134-140.

35. Cabello CM, Bair WB, Lamore SD, Ley S, Bause AS, Azimian S, Wondrak GT. The cinnamon-derived Michael acceptor cinnamic aldehyde impairs melanoma cell proliferation, invasiveness, and tumor growth. Free Radic Biol Med. 2009;46(2): 220-31.

36. Gasparini L, Xu H. Potential roles of insulin and IGF-1 in Alzheimer's disease. Trends Neurosci. 2003;26: 404-406 
37. Wang W, Wu N, Zu Y, Fu Y. Antioxidative activity of Rosmarinus officinalis L. essential oil compared to its main components. Food Chem. 2008;108: 1019-1022.

38. Saker AS, Hawazen AL. Protective Effect of Rosemary (Rosmarinus officinalis) Leaves Extract on Carbon Tetrachloride-Induced Nephrotoxicity in Albino Rats. Life Sci J. 2012;9: 779-785.

39. Moon DO, Kim MO, Lee JD, Choi YH, Kim GY. (2010). Rosmarinic acid sensitizes cell death through suppression of TNF-alpha-induced NF-kappaB activation and ROS generation in human leukemiaU937 cells. Cancer Lett. 288: 183-91.

40. Cheng AC, Lee MF, Tsai ML, Lai CS, Lee JH, Ho CT, Pan MH. (2011) Rosmanol potently induces apoptosis through both the mitochondrial apoptotic pathway and death receptor pathway in human colon adenocarcinoma COLO 205 cells. Food Chem Toxicol. 2011;49(2):

41. Kim KH, Seo HS, Choi HS, Choi I, Shin YC, Ko, SG. Induction of apoptotic cell death by ursolic acid through mitochondrial death pathway and extrinsic death receptor pathway in MDA-MB-231 cells. Arch Pharm Res. 2011;34(8): 1363-72.

42. Jiang X, Wang X. Cytochrome C-mediated apoptosis. Annu Rev Biochem 2004; 73 : 87-106
43. Tuncer E, Unver-Saraydin S, Tepe B, Karadayi S, Ozer H, Karadayi K, Inan D, Elagoz S, Polat Z, Duma M, Turan M. Antitumor effects of Origanum acutidens extracts on human breast cancer. J Buon. 2013;18(1): 77-85.

44. Al-Kalaldeh JZ, Abu-Dahab R, Afifi FU. Volatile oil composition and antiproliferative activity of Laurus nobilis, Origanum syriacum, Origanum vulgare, and Salvia triloba against human breast adenocarcinoma cells. Nutr Res. 2010;30(4): 271-8.

45. Yin Q, Yan F, Zu X, Wu Y, Wu X, Liao M, Deng S, Yin L, Zhuang Y. Antiproliferative and proapoptotic effect of carvacrol on human hepatocellular carcinoma cell line HepG-2. Cytotech. 2012;64(1): 43-51.

46. Sriharia T. Role of oregano on bacterial enzymes in 1,2-dimethyl hydrazine-incluced experimental colon carrinogenesis, Can $J$ Physio Pharm. 2008;86 (10): 667-674.

47. Shaban A, Seyed A, Ali R. Antineoplastic effect of Fenugreek (Trigonella Foenum Graecum) seed extract against acute myeloblastic leukemia cell line (KG-1). Iran J Blood Cancer. 2009;1(4): 139-146.

48. Stanojković TP, Konić-Ristić A, Juranić ZD, Savikin K, Zdunić G, Menković N, Jadranin M. Cytotoxic and cell cycle effects induced by two herbal extract on human cervix carcinoma and human breast cancer cell lines. J Med Food. 2010;13(2): 291-7. 